\title{
The role of the PTEN gene in malignant gliomas
}

\section{Znaczenie genu PTEN w glejakach złośliwych}

\author{
George A. Alexiou, Spyridon Voulgaris \\ Department of Neurosurgery, University Hospital of loannina, loannina, Greece
}

Neurologia i Neurochirurgia Polska 2010; 44, 1: 80-86

\begin{abstract}
This article focuses on the latest data about the role of the gene for phosphatase and tensin homologue located on chromosome 10 (PTEN) in malignant gliomas. PTEN acts as a tumour suppressor gene and plays a critical role in cell cycle progression, angiogenesis, migration, invasions and stem cell regulation. Furthermore, there is an interaction with other tumour suppressor genes. We discuss the role of miRNAs in modulating PTEN expression and also PTEN's role in the nucleus.
\end{abstract}

Key words: PTEN, AKT, glioma.

\section{Introduction}

Malignant gliomas are the most common type of primary brain tumours. Treatment remains difficult despite the large amount of research undertaken. The median survival from the time of diagnosis is one year on average for glioblastoma multiforme (GBM) and three years for anaplastic astrocytomas $[1,2]$. The most aggressive GBM is characterized by uncontrolled proliferation, high levels of neovascularization, diffuse infiltration, resistance to death-inducing stimuli and necrosis [3]. Several genetic alterations have been found in malignant gliomas such as gene mutations, amplifications, loss of heterozygosity or deletions that

\section{Streszczenie}

W artykule przedstawiono najnowsze dane dotyczące roli genu dla homologu fosfatazy i tensyny $(P T E N)$ w glejakach złośliwych. PTEN działa jako gen supresorowy nowotworzenia i odgrywa kluczową rolę w przebiegu cyklu komórkowego, w angiogenezie, migracji, inwazyjności i regulacji komórek macierzystych. Wchodzi ponadto $\mathrm{w}$ interakcje $\mathrm{z}$ innym genami supresorowymi nowotworzenia. $\mathrm{W}$ artykule omówiono znaczenie miRNA w modulowaniu ekspresji PTEN oraz rolę, którą PTEN odgrywa w jądrze komórkowym.

\section{Słowa kluczowe: PTEN, AKT, glejak.}

give promise to the development of more targeted and effective therapies.

Phosphatase and tensin homologue located on chromosome 10 (10q23.3) (PTEN) was identified in 1997 as a tumour suppressor gene $[4,5]$. PTEN has been found mutated in a large number of cancers at high frequency, including brain tumours [6,7]. PTEN mutations have been found in as many as $20-40 \%$ of GBM, mainly in primary GBM $[3,8]$. The PTEN structure reveals an $\mathrm{N}$-terminal phosphatase domain, a $\mathrm{C} 2$ domain and the C-terminal tail and is a dual protein and lipid phosphatase. The identification of PTEN mutants, which have defects in either lipid or both lipid and protein phosphatase activities, has made it possible to further

Correspondence address: Alexiou George, MD, P.0. BOX 103, Neohoropoulo loannina, 45500 Greece, phone +302651048795 ,

+306948 525134,e-mail: alexiougrg@yahoo.gr

Received: 23.09.2009; accepted: 16.11.2009 
clarify PTEN's function. The protein contains a tensin-like domain as well as a catalytic domain, dephosphorylating serine, threonine, and tyrosine phosphorylated proteins [9]. As a lipid phosphatase, PTEN dephosphorylates the intracellular levels of phosphatidylinositol $(3,4,5)$-triphosphate $\left(\mathrm{PIP}_{3}\right)$, a product of phosphoinositide-3-kinase (PI3K), to create phosphatidylinositol $(4,5)$-bisphosphate $\left(\mathrm{PIP}_{2}\right)$. Moreover, PTEN is the sole central negative regulator of PI3K signalling because no other protein compensates if there is a loss in its function. PTEN disruption leads to $\mathrm{PIP}_{3}$ accumulation which activates a cascade of signalling molecules including the phosphatidylinositol-dependent kinases (PDKs), the serine/threonine kinases AKT/protein kinase $\mathrm{B}, \mathrm{S} 6$ kinase, and $\mathrm{mTOR}$, as well as small GTPases Rac1 and Cdc42. One of the most studied PTEN downstream effects is the activation of AKT, which regulates angiogenesis via activation of hypoxia-inducible factor-1 (HIF-1) and VEGF, cell migration and invasion through matrix metalloproteinases (MMP) regulation, cell cycle progression through down-regulation of the G1 cell cycle inhibitor, p21 and p27, cell survival through the inhibition of proapoptotic factors such as BAD, BIM, FAS ligand and caspase 9, cell growth via the activation of mTOR and corticogenesis via the mediation of insulinlike growth factor-1 (IGF-1) [10,11] (Fig. 1). Furthermore, loss in PTEN function results in high levels of insulin-like growth factor binding protein-2 (IGFBP-2) expression via the loss of its lipid phosphatase activity [9]. IGFBP-2 can act as a growth stimulator and there are reports of a positive correlation between IGFBP-2 expression and grade of gliomas $[12,13]$.

\section{PTEN and p53}

P53, a crucial tumour suppressor gene, has an important role in the transcriptional activation of genes involved in cell cycle control, DNA repair, senescence, angiogenesis, and apoptosis. P53 mutations are the most frequent in human cancers [14]. Several studies have reported that PTEN and p53 are linked up. It has been shown that PTEN transcription can be regulated by $\mathrm{p} 53$ because the PTEN promoter contains a p53-binding site element that is required for the transactivation of PTEN [15]. Loss of p53 resulted in reduction of PTEN expression and increased ultraviolet-induced AKT activation in 293T glioma cells as demonstrated by Chappell et al. [16]. On the other hand, p53 may

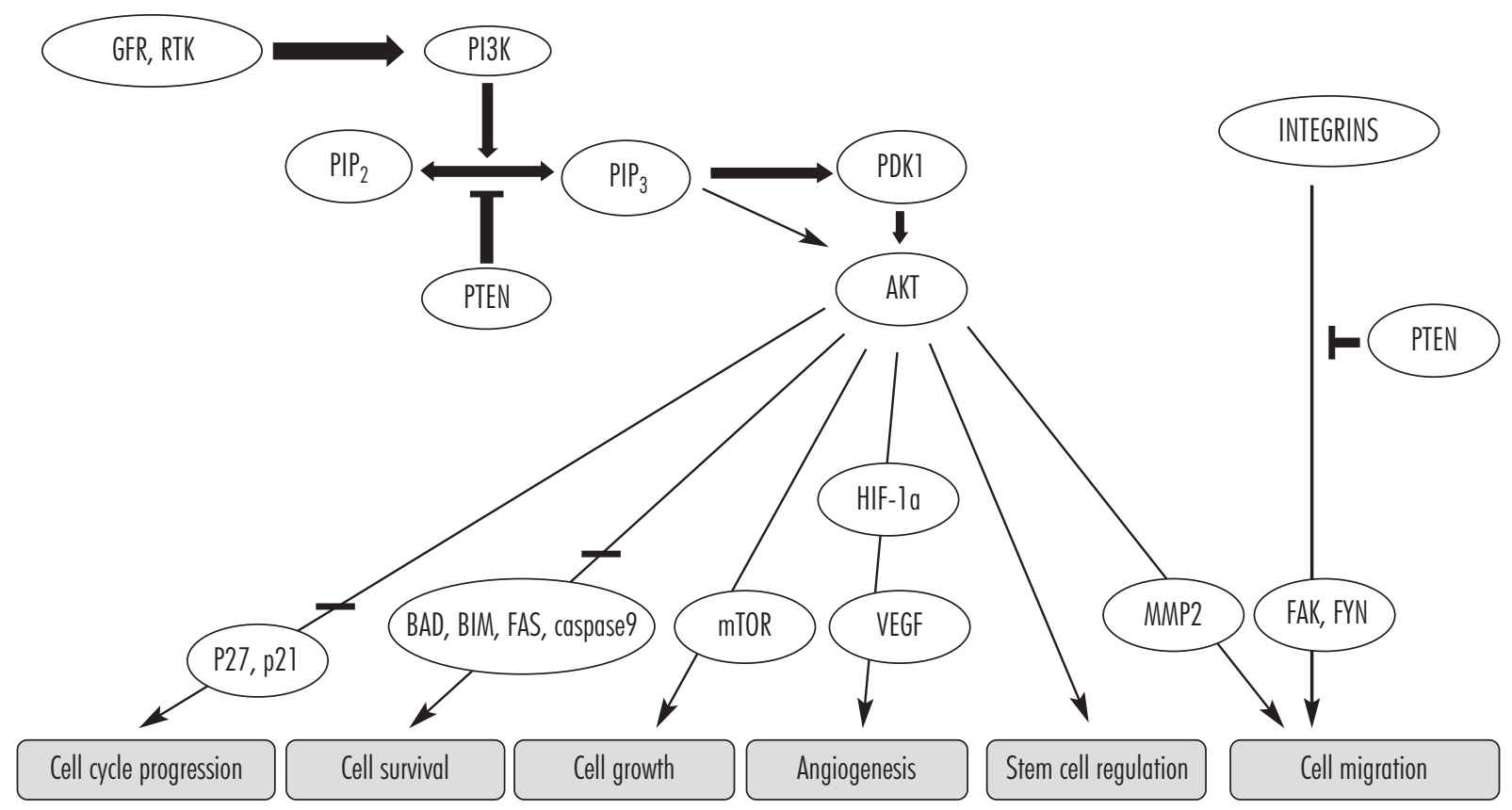

Fig. 1. Representation of the Pten/PI3K/Akt signalling pathway. PI3K can be activated by growth factor receptors and tyrosine kinase receptors. PI3K induces the production of PIP3 which activates AKT. PTEN antagonizes PI3K signals. AKT regulates cell cycle progression (down-regulation of p2I and p27), cell survival (via inhibition of BAD, BIM, FAS ligand and caspase 9), cell growth (via activation of mTOR, a growth regulator), angiogenesis (activation of HIF-I and VEGF), stem cell and cell migration and invasion through the regulation of MMPS. PTEN dephosphorylates focal adhesion kinases (FAK) and SRC family kinases (FYN) 
down-regulate PTEN partially by activating caspases under stress induced by proteasome inhibition [17].

\section{PTEN and miRNAs}

MicroRNAs (miRNAs) are small (18-25 nt) noncoding RNAs implicated in the pathogenesis of various malignancies by regulating the expression of several tumour suppressors and oncogenes [18]. MiR-19a and miR-21 have been reported to specifically target and to down-regulate PTEN $[18,19]$. Furthermore, PTEN is regulated by miR-214, which directly binds the PTEN 3'-UTR leading to inhibition of PTEN translation and subsequent activation of the PI3K/AKT pathway [20]. Huse et al. reported that miR-26a, another downregulator of PTEN expression, is usually amplified in gliomas. PTEN suppression by miR-26a in a murine glioma model enhanced de novo tumour formation and precluded loss of heterozygosity and the PTEN locus [21].

\section{Nuclear PTEN}

Research into PTEN revealed that apart from its cytoplasmic localization, it can be found mainly in the nucleus of normal cells $[22,23]$. Subsequent research revealed that loss of the nuclear PTEN can be found in a variety of tumours $[24,25]$. This leads to the belief that nuclear PTEN may be involved in neoplastic transformation and that might modulate its activity. Nevertheless, PTEN does not contain any obvious nuclear import/export signal. Several mechanisms have been implicated for the nuclear import of PTEN, such as simple diffusion [26], phosphorylation-dependent transfer [27], active transport through NLS-like signals [28], interaction with the major vault protein mediated by $\mathrm{Ca}^{2+}$ signalling [29] and monoubiquitylation of PTEN at K289 [30].

One of the functions of nuclear PTEN is the control of AKT activity, since PI3K, PDK1 and activated AKT can be found in the nucleus. Furthermore, nuclear PTEN also induces a G0-G1 arrest by decreasing the cyclin D1 levels [31]. Liu et al. recently found that nuclear PTEN can suppress anchorage-independent growth and facilitate G1 arrest in U251MG glioma cells without inhibiting AKT activity [32]. Moreover, Gil et al. showed that apoptotic stimulation, via $\mathrm{TNFa}$ in U87MG glioma cells, increased the nuclear accumulation of PTEN. The overexpression of catalyti- cally active nuclear PTEN enhanced cell apoptotic responses in U87MG glioma cells [33].

\section{Specific functions of PTEN}

\section{Cell cycle progression}

Loss of PTEN function in astrocytes results in increased proliferation [49]. Several studies have reported that re-expression of PTEN in PTEN-deficient glioblastoma cell lines suppresses proliferation in vitro [33-36]. Cell cycle arrest in the G1 phase is the mechanism for the proliferation defect induced by PTEN in most glioblastoma cells $[35,37]$. Activation of the PI3K pathway has been shown to regulate cell-cycle progression directly through AKT-mediated phosphorylation of cell cycle inhibitors, such as p27, p21 and GsK3 $3[39,40]$. Id-1 is a novel PTEN inhibitor, acting by down-regulation of p53 expression, that activates the PI3K/AKT signalling pathway and affects its downstream effectors, the Wnt/T-cell factor (TCF) pathway and $\mathrm{p} 27 \mathrm{Kip} 1$ phosphorylation and its cytosolic retention [41].

\section{Angiogenesis}

Mutation of PTEN has been observed mainly in high grade gliomas in which neovascularization is present. Consequently, there has been an effort to elucidate PTEN's role. Hypoxia, VEGF, acidic fibroblast growth factor, IL-6 and IL-8 are known inducers of angiogenesis, whereas angiostatin, endostatin, thrombospondin 1 (TSP1) and endothelial monocyteactivating polypeptide 2 are suppressors [42]. Overexpression of AKT1 in endothelial cells of adult mice resulted in formation of pathological blood vessels. Wen et al. reported that the reconstitution of wild-type PTEN in U87MG glioma cells lines dramatically decreased tumour growth in vivo and prolonged survival in mice implanted intracranially with these tumour cells, but had no effect on in vitro proliferation. PTEN reconstitution diminished phosphorylation of AKT within the PTEN-reconstituted tumour, induced TSP1 expression, and suppressed angiogenic activity. Using an inactive mutant of PTEN they found that the lipid phosphatase activity of PTEN regulates the angiogenic response in vivo [43]. Su et al. showed that PTEN induced the transactivation of $\mathrm{p} 53$ and increased 
the expression of p53 target genes [44]. P53 is one transcription factor that up-regulates TSP-1 [45].

The tumour vasculature may also be directly influenced by the fluctuating hypoxic environment. HIF-1, a key regulator of the cellular response to hypoxia, is a heterodimeric transcription factor composed of the nearly ubiquitous HIF-1 $\alpha$ and its dimerization partner HIF-1 $\beta$ [46]. Under non-hypoxic conditions, HIF-1 $\alpha$ is subject to ubiquitination and proteosomal degradation [47]. However, under hypoxic conditions HIF1 $\alpha$ is stabilized and forms a dimer with HIF-1 $\beta$ to become an active transcription factor [48]. PI3K/AKT signalling modulates the HIF-1 $\alpha$ pathway. It has been found that AKT activation induces VEGF and HIF-1 expression through its two downstream molecules HDM2 and p70S6K1. VEGF and HIF-1 are the mediators that transmit PI3K-induced oncogenic signals for tumour growth and angiogenesis. Consequently, loss of PTEN can increase HIF-1 activity in glioma cell lines [48-50]. Emerling et al. found that the phosphatase action of the nuclear PTEN is required for the repression of HIF-1 transcriptional activity through the inactivation of Forkhead transcription factor $3 \mathrm{a}$ (FOXO3a). FOXO3 is a negative regulator of HIF-1 transcriptional activity by interfering with the ability of p300 to serve as a transcriptional coactivator [51].

Increased glycolysis is characteristic of malignancy. Beckner et al. reported that glycolytic enzymes were abundant and some were increased in pseudopodia formed by U87 glioma cells [52]. Activation of AKT, a critical downstream target of PTEN signalling, triggers enhanced glycolytic activity and aerobic glycolysis that produce lactate and pyruvate [53]. Lactate is also a known instigator of cytokines and growth factors such as VEGF, TGF- $\beta$, and IL-1. Lactate stabilizes HIF-1 $\alpha$ even in the presence of oxygen because lactate and pyruvate bind to and inhibit the HIF prolyl hydroxylases that would otherwise hydroxylate HIF-1 $\alpha$ and mark it for rapid degradation $[54,55]$. Hunt et al. reported that accumulated lactate appeared to convey the impression of "metabolic need" for vascularization even in welloxygenated and pH-neutral conditions [56]. This constitutes another possible role of PTEN in angiogenesis through the regulation of cell metabolism.

\section{Migration and invasion}

Tumour invasion involves cell migration from the primary tumour site to distant normal tissue. Tumour cells have the propensity to adhere to the extracellular matrix (ECM) and degrade it with proteolytic enzymes [57]. PTEN over-expression was shown to be able to inhibit the migration and spreading of U87MG and DBTRG glioblastoma cells. Focal adhesion kinase (FAK) was proposed as a potential substrate for PTEN [58]. Furukawa et al. showed that PTEN significantly decreased cell migration in both U251 and U373 glioma cells by decreasing the phosphorylation levels of FAK. Furthermore, PTEN decreases the levels of Cdc42-GTP-binding protein and Rac-GTP, which are directly related to the motile activity of cells. Regarding tumour cells' ability to regulate the ECM, there is an inhibitory effect of PTEN on the proteolytic activity of MMP [59].

Liliental et al. reported that PTEN influences migration by regulation of Rac1 and Cdc42 in a lipid phosphatase-dependent manner [60]. Nevertheless, in microinjected glioblastoma cell monolayers, the C2 domain of PTEN alone was able to block cell migration, suggesting that in order to inhibit migration, PTEN requires protein phosphatase activity to autodephosphorylate its C-terminal phosphorylation sites [61]. PTEN G129E, lacking PtdIns(3,4,5)P3 phosphatase activity, could inhibit cell motility as efficiently as the wildtype enzyme, when expressed through microinjection of expression constructs into PTEN null glioblastoma cells [61]. A similar conclusion was supported by in vivo studies in the early chick embryo [62]. Furthermore, PTEN regulates integrin-directed migration not in a PI3K-dependent but in a protein phosphatase-dependent manner, through the control over the activity of SRC family kinases (specifically FYN) [63].

Protein kinase $\mathrm{C}$ type $\mathrm{i}(\mathrm{PKC} \mathrm{i}$ ), which is a member of the atypical protein kinase $\mathrm{C}$ and downstream mediator activated by the PI3K pathway, has an important role in cell motility and invasion by repressing the expression of mRNA for RhoB. RhoB is a member of the Rho GTPase family of proteins that regulates a variety of cellular processes including actin organization, proliferation and differentiation [64]. Expression of RhoB in U87 and A172 glioma cells significantly reduced their motility. The inhibition of PI3k from PTEN results in an increase in RhoB levels [65].

\section{Stem cell regulation}

Cancer stem cells have been implicated as initiators for the development of brain tumours. Dirks and colleagues initially showed that human GBM xenografts into immunodeficient mice have this identifiable subset 
of cancer-propagating cells or cancer stem cells [66]. In adult people, stem cells represent a relatively inactive subpopulation, which can enter the cell cycle upon growth factor stimulation to replenish specific cellular populations and then exit the cycle ( $\mathrm{G} 0$ cell cycle state). Recent studies have shown that mutations in the stem/progenitor compartment account for the majority of these tumours and neural stem/progenitor cells as cancer-initiating cells have been identified in astrocytoma mouse models. Furthermore, astrocytoma induction occurs efficiently in embryonic, early postnatal, and adult mice dependent on stem/progenitor cell targeting of the tumour suppressors. Deletion of PTEN has been shown to regulate neural stem cell selfrenewal [67] and proliferation [68,69]. Sinor et al. demonstrated that overexpression of AKT-1, a critical downstream target of PTEN signalling, resulted in enhanced self-renewal of cortical progenitor cells [70]. Furthermore, Groszer et al. reported that the loss of PTEN enhances G0 cell cycle exit and self-renewal capacity and decreases growth factor dependence [69].

PTEN appears to influence neuronal and astrocyte differentiation [71]. Yue et al. reported that PTEN is involved in the differentiation of cerebellar Bergmann glia cells [72]. Chang-Hyuk Kwon et al. developed genetic mouse models for de novo GBM that support the idea that in the presence of NF1, p53 and PTEN heterozygosity, de novo high-grade gliomas appear without requisite transition through low-grade status, undergoing $\mathrm{LOH}$ at $\mathrm{NF1}$ and p53, yet retaining PTEN heterozygosity. PTEN heterozygosity confers haploinsufficiency for de novo high-grade tumour formation [73].

\section{Prognostic significance of PTEN mutation}

Clinical studies have revealed that PTEN mutation in glioblastoma has no correlation with survival [74]. Nevertheless, in anaplastic oligodendrogliomas and astrocytomas there was a positive correlation between PTEN alterations and poor prognosis [74,75]. Furthermore, elevated AKT activity has been associated with poor prognosis [76]. Paediatric patients harbouring PTEN mutation in tumours have poorer prognosis [77]. Thorarinsdottir et al. reported that deficient PTEN expression was associated with worse overall survival in childhood high grade gliomas [78].

\section{Conclusions}

PTEN has been established as an important tumour suppressor gene. Understanding of the integration of biochemical pathways involved in both tumorigenesis and cancer suppression is a key to the development of improved pharmacological treatment strategies for cancer. The continuously improving knowledge of the PTEN/PI3K/AKT pathway can lead to the development of promising and effective molecular therapeutic regimens that specifically inhibit key effector proteins in this pathway and hold promise to an effective glioma treatment.

\section{Acknowledgment}

We would like to thank Ms Elizabeth Papanikolaou for manuscript editing.

\section{Disclosure}

Authors report no conflict of interest.

\section{References}

1. Buckner J.C. Factors influencing survival in high-grade gliomas. Semin Oncol 2003; 30: 10-14.

2. Nabors L.B., Fiveash J. Treatment of adults with recurrent malignant glioma. Expert Rev Neurother 2005; 5: 509-514.

3. Furnari F.B., Fenton T., Bachoo R.M., et al. Malignant astrocytic glioma: genetics, biology, and paths to treatment. Genes Dev 2007; 21: 2683-2710.

4. Li J., Simpson L., Takahashi M., et al. The Pten/MMAC1 tumor suppressor induces cell death that is rescued by the Akt/protein kinase B oncogene. Cancer Res 1997; 58: 5667-5672.

5. Li D.M., Sun H. TEP1, encoded by a candidate tumor suppressor locus, is a novel protein tyrosine phosphatase regulated by transforming growth factor beta. Cancer Res 1997; 57: 2124-2129.

6. Li J., Yen C., Liaw D., et al. PTEN: a putative protein tyrosine phosphatase gene mutated in human brain, breast, and prostate cancer. Science 1997; 275: 1943-1947.

7. Cully M., You H., Levine A.J., et al. Beyond PTEN mutations: the PI3K pathway as an integrator of multiple inputs during tumorigenesis. Nat Rev Cancer 2006; 6: 184-192.

8. Duerr E.M., Rollbrocker B., Hayashi Y., et al. PTEN mutations in gliomas and glioneuronal tumors. Oncogene 1998; 16: 2259-2264.

9. Levitt R.J., Georgescu M.M., Pollak M. PTEN-induction in U251 glioma cells decreases the expression of insulin-like growth factor binding protein-2. Biochem Biophys Res Commun 2005; 336: 1056-1061. 
10. Blanco-Aparicio C., Renner O., Leal J.F., et al. PTEN, more than the AKT pathway. Carcinogenesis 2007; 28: 1379-1386.

11. Mairet-Coello G., Tury A., DiCicco-Bloom E. Insulin-like growth factor-1 promotes $\mathrm{G}(1) / \mathrm{S}$ cell cycle progression through bidirectional regulation of cyclins and cyclin-dependent kinase inhibitors via the phosphatidylinositol 3-kinase/Akt pathway in developing rat cerebral cortex. J Neurosci 2009; 29: 775-788.

12. Fuller G.N., Rhee C.H., Hess K.R., et al. Reactivation of insulin-like growth factor binding protein 2 expression in glioblastoma multiforme: a revelation by parallel gene expression profiling. Cancer Res 1999; 13: 4228-4232.

13. Godard S., Getz G.M., Delorenzi P., et al. Classification of human astrocytic gliomas on the basis of gene expression: a correlated group of genes with angiogenic activity emerges as a strong predictor of subtypes. Cancer Res 2003; 63: 6613-6625.

14. Levine A.J., Finlay C.A., Hinds P.W. P53 is a tumor suppressor gene. Cell 2004; 23: 116.

15. Stambolic V., MacPherson D., Sas D., et al. Regulation of PTEN transcription by p53. Mol Cell 2001; 8: 317-325.

16. Chappell W.H., Green T.D., Spengeman J.D., et al. Increased protein expression of the PTEN tumor suppressor in the presence of constitutively active Notch-1. Cell Cycle 2005; 4: 1389-1395.

17. Tang Y., Eng C. p53 down-regulates phosphatase and tensin homologue deleted on chromosome 10 protein stability partially through caspase-mediated degradation in cells with proteasome dysfunction. Cancer Res 2006; 66: 6139-6148.

18. Lewis B.P., Shih I.H., Jones-Rhoades M.W., et al. Prediction of mammalian microRNA targets. Cell 2003; 115: 787-798.

19. Meng F., Henson R., Lang M., et al. Involvement of human micro-RNA in growth and response to chemotherapy in human cholangiocarcinoma cell lines. Gastroenterology 2006; 130: 2113 2129.

20. Bueno M.J., de Castro I.P., Malumbres M. Control of cell proliferation pathways by microRNAs. Cell Cycle 2008; 7: 31433148.

21. Huse J.T., Brennan C., Hambardzumyan D., et al. The PTENregulating microRNA miR-26a is amplified in high-grade glioma and facilitates gliomagenesis in vivo. Genes Dev 2009; 23: $1327-1337$

22. Sano T., Lin H., Chen X., et al. Differential expression of MMAC/PTEN in glioblastoma multiforme: relationship to localization and prognosis. Cancer Res 1999; 59: 1820-1824.

23. Perren A., Weng L.P., Boag A.H., et al. Immunohistochemical evidence of loss of PTEN expression in primary ductal adenocarcinomas of the breast. Am J Pathol 1999; 155: 1253-1260.

24. Dreher T., Zentgraf H., Abel U., et al. Reduction of PTEN and $\mathrm{p} 27 \mathrm{kip} 1$ expression correlates with tumor grade in prostate cancer. Analysis in radical prostatectomy specimens and needle biopsies. Virchowes Arch 2004; 444: 509-517.

25. Perren A., Komminoth P., Saremaslani P., et al. Mutation and expression analyses reveal differential subcellular compartmentalization of PTEN in endocrine pancreatic tumors compared to normal islet cells. Am J Pathol 2000; 157: 1097-1103.

26. Liu F., Wagner S., Campbell R.B., et al. PTEN enters the nucleus by diffusion. J Cell Biochem 2005; 96: 221-234.

27. Chang C.J., Mulholland D.J., Valamehr B., et al. PTEN nuclear localization is regulated by oxidative stress and mediates $\mathrm{p} 53$ dependent tumor suppression. Mol Cell Biol 2008; 28: 3281-3289.
28. Chung J.H., Ginn-Pease M.E., Eng C. Phosphatase and tensin homologue deleted on chromosome 10 (PTEN) has nuclear localization signal-like sequences for nuclear import mediated by major vault protein. Cancer Res 2005; 65: 4108-4116.

29. Minaguchi T., Waite K.A., Eng C. Nuclear localization of PTEN is regulated by $\mathrm{Ca}(2+)$ through a tyrosil phosphorylation-independent conformational modification in major vault protein. Cancer Res 2006; 66: 11677-11682.

30. Trotman L.C., Wang X., Alimonti A., et al. Ubiquitination regulates PTEN nuclear import and tumor suppression. Cell 2007; 128: 141-156.

31. Planchon S.M., Waite K.A., Eng C. The nuclear affairs of PTEN. J Cell Sci 2008; 121: 249-253.

32. Liu J.L., Sheng X., Hortobagyi Z.K., et al. Nuclear PTENmediated growth suppression is independent of Akt downregulation. Mol Cell Biol 2005; 25: 6211-6224.

33. Gil A., Andrés-Pons A., Fernández E., et al. Nuclear localization of PTEN by a Ran-dependent mechanism enhances apoptosis: Involvement of an N-terminal nuclear localization domain and multiple nuclear exclusion motifs. Mol Biol Cell 2006; 17: 40024013.

34. Fraser M.M., Zhu X., Kwon C.H., et al. PTEN loss causes hypertrophy and increased proliferation of astrocytes in vivo. Cancer Res 2004; 64: 7773-7739.

35. Cheney I.W., Johnson D.E., Vaillancourt M.T., et al. Suppression of tumorigenicity of glioblastoma cells by adenovirusmediated MMAC1/PTEN gene transfer. Cancer Res 1998; 58 : 2331-2334.

36. Furnari F.B., Lin H., Huang H.S., et al. Growth suppression of glioma cells by PTEN requires a functional phosphatase catalytic domain. Proc Natl Acad Sci U S A 1997; 94: 12479-12484.

37. Furnari F.B., Huang H.J., Cavenee W.K. The phosphoinositol phosphatase activity of PTEN mediates a serum-sensitive G1 growth arrest in glioma cells. Cancer Res 1998; 58: 5002-5008.

38. Li D.M., Sun H. PTEN/MMAC1/TEP1 suppresses the tumorigenicity and induces G1 cell cycle arrest in human glioblastoma cells. Proc Natl Acad Sci U S A 1998; 95: 1540615411.

39. Gottschalk A.R., Basila D., Wong M., et al. p27Kip1 is required for PTEN-induced G1 growth arrest. Cancer Res 2001; 61: 2105-2111.

40. Cheney I.W., Neuteboom S.T., Vaillancourt M.T., et al. Adenovirus-mediated gene transfer of MMAC1/PTEN to glioblastoma cells inhibits $\mathrm{S}$ phase entry by the recruitment of p27Kip1 into cyclin E/CDK2 complexes. Cancer Res 1999; 59: 2318-2323.

41. Lee J.Y., Kang M.B., Jang S.H., et al. Id-1 activates Aktmediated Wnt signaling and p27(Kip1) phosphorylation through PTEN inhibition. Oncogene 2009; 28: 824-831.

42. Castellino R.C., Durden D.L. Mechanisms of disease: the PI3K-Akt-PTEN signaling node - an intercept point for the control of angiogenesis in brain tumors. Nat Clin Pract Neurol 2007; 3: 682-693.

43. Wen S., Stolarov J., Myers M.P., et al. PTEN controls tumorinduced angiogenesis. Proc Natl Acad Sci U S A 2001; 98: 46224627.

44. Su J.D., Mayo L.D., Donner D.B., et al. PTEN and phosphatidylinositol 3'-kinase inhibitors up-regulate p53 and 
block tumor-induced angiogenesis: evidence for an effect on the tumor and endothelial compartment. Cancer Res 2003; 63: 3585-3592.

45. Dameron K.M., Volpert O.V., Tainsky M.A., et al. Control of angiogenesis in fibroblasts by p53 regulation of thrombospondin-1. Science 1994; 265: 1582-1584.

46. Schofield C.J., Ratcliffe P.J. Oxygen sensing by HIF hydroxylases. Nat Rev Mol Cell Biol 2004; 5: 343-354.

47. Laughner E., Taghavi P., Chiles K., et al. HER2 (neu) signaling increases the rate of hypoxia-inducible factor 1alpha (HIF1alpha) synthesis: novel mechanism for HIF-1-mediated vascular endothelial growth factor expression. Mol Cell Biol 2001; 21: 3995-4004.

48. Zhong H., Chiles K., Feldser D., et al. Modulation of hypoxiainducible factor 1alpha expression by the epidermal growth factor/phosphatidylinositol 3-kinase/PTEN/AKT/FRAP pathway in human prostate cancer cells: implications for tumor angiogenesis and therapeutics. Cancer Res 2000; 60: 1541-1545.

49. Zundel W., Schindler C., Haas-Kogan D., et al. Loss of PTEN facilitates HIF-1-mediated gene expression. Genes Dev 2000; 14: 391-396.

50. Jiang B.H., Jiang G., Zheng J.Z., et al. Phosphatidylinositol 3-kinase signaling controls levels of hypoxia-inducible factor 1 . Cell Growth Differ 2001; 12: 363-369.

51. Emerling B.M., Weinberg F., Liu J.L., et al. PTEN regulates p300-dependent hypoxia-inducible factor 1 transcriptional activity through Forkhead transcription factor 3a (FOXO3a). Proc Natl Acad Sci U S A 2008; 105: 2622-2627.

52. Beckner M.E., Chen X., An J., et al. Proteomic characterization of harvested pseudopodia with differential gel electrophoresis and specific antibodies. Lab Invest 2005; 85: 316-327.

53. Elstrom R.L., Bauer D.E., Buzzai M., et al. Akt stimulates aerobic glycolysis in cancer cells. Cancer Res 2004; 64: 3892-3899.

54. Lu H., Dalgard C.L., Mohyeldin A., et al. Reversible inactivation of HIF-1 prolyl hydroxylases allows cell metabolism to control basal HIF-1. J Biol Chem 2005; 280: 41928-41939.

55. Lu H., Forbes R.A., Verma A. Hypoxia-inducible factor 1 activation by aerobic glycolysis implicates the Warburg effect in carcinogenesis. J Biol Chem 2002; 277: 23111-23115.

56. Hunt T.K., Aslam R.S., Beckert S., et al. Aerobically derived lactate stimulates revascularization and tissue repair via redox mechanisms. Antioxid Redox Signal 2007; 9: 1115-1124.

57. Liotta L.A., Rao C.N., Wewer U.M. Biochemical interactions of tumor cells with the basement membrane. Anmu Rev Biochem 1986; 55: 1037-1057.

58. Tamura M., Gu J., Matsumoto K., et al. Inhibition of cell migration, spreading, and focal adhesions by tumor suppressor PTEN. Science 1998; 280: 1614-1617.

59. Furukawa K., Kumon Y., Harada H., et al. PTEN gene transfer suppresses the invasive potential of human malignant gliomas by regulating cell invasion-related molecules. Int J Oncol 2006; 29: 73-81.

60. Liliental J., Moon S.Y., Lesche R., et al. Genetic deletion of the Pten tumor suppressor gene promotes cell motility by activation of Rac1 and Cdc42 GTPases. Curr Biol 2000; 10: 401-404.

61. Raftopoulou M., Etienne-Manneville S., Self A., et al. Regulation of cell migration by the $\mathrm{C} 2$ domain of the tumor suppressor PTEN. Science 2004; 303: 1179-1181.
62. Leslie N.R., Yang X., Downes C.P., et al. PtdIns(3,4,5)P(3)dependent and independent roles for PTEN in the control of cell migration. Curr Biol 2007; 17: 115-125.

63. Dey N., Crosswell H.E., De P., et al. The protein phosphatase activity of PTEN regulates SRC family kinases and controls glioma migration. Cancer Res 2008; 68: 1862-1871.

64. Wheeler A.P., Ridley A.J. Why three Rho proteins? RhoA, RhoB, RhoC, and cell motility. Exp Cell Res 2004; 301: 43-49.

65. Baldwin R.M., Parolin D.A., Lorimer I.A. Regulation of glioblastoma cell invasion by $\mathrm{PKC}$ iota and RhoB. Oncogene 2008; 27: 3587-3595.

66. Singh S.K., Hawkins C., Clarke I.D., et al. Identification of human brain tumour initiating cells. Nature 2004; 432: 396-401.

67. Groszer M., Erickson R., Scripture-Adams D.D., et al. Negative regulation of neural stem/progenitor cell proliferation by the Pten tumor suppressor gene in vivo. Science 2001; 294: 2186-2189.

68. Li L., Liu F., Salmonsen R.A., et al. PTEN in neural precursor cells: regulation of migration, apoptosis, and proliferation. $\mathrm{Mol}$ Cell Neurosci 2002; 20: 21-29.

69. Groszer M., Erickson R., Scripture-Adams D.D., et al. PTEN negatively regulates neural stem cell self-renewal by modulating G0-G1 cell cycle entry. Proc Natl Acad Sci U S A 2006; 103: 111-116.

70. Sinor A.D., Lillien L. Akt-1 expression level regulates CNS precursors. J Neurosci 2004; 24: 8531-8541.

71. Otaegi G., Yusta-Boyo M.J., Vergaño-Vera E., et al. Modulation of the PI 3-kinase-Akt signalling pathway by IGF-I and PTEN regulates the differentiation of neural stem/precursor cells. J Cell Sci 2006; 119: 2739-2748.

72. Yue Q., Groszer M., Gil J.S., et al. PTEN deletion in Bergmann glia leads to premature differentiation and affects laminar organization. Development 2005; 132: 3281-3291.

73. Kwon C.H., Zhao D., Chen J., et al. Pten haploinsufficiency accelerates formation of high-grade astrocytomas. Cancer Res 2008; 68: 3286-3294.

74. Smith J.S., Tachibana I., Passe S.M., et al. PTEN mutation, EGFR amplification, and outcome in patients with anaplastic astrocytoma and glioblastoma multiforme. J Natl Cancer Inst 2001; 93: 1246-1256.

75. Sasaki H., Zlatescu M.C., Betensky R.A., et al. PTEN is a target of chromosome 10q loss in anaplastic oligodendrogliomas and PTEN alterations are associated with poor prognosis. Am J Pathol 2001; 159: 359-367.

76. Ermoian R.P., Furniss C.S., Lamborn K.R., et al. Dysregulation of PTEN and protein kinase B is associated with glioma histology and patient survival. Clin Cancer Res 2002; 8: 11001106.

77. Raffel C., Frederick L., O'Fallon J.R., et al. Analysis of oncogene and tumor suppressor gene alterations in pediatric malignant astrocytomas reveals reduced survival for patients with PTEN mutations. Clin Cancer Res 1999; 5: 4085-4090.

78. Thorarinsdottir H.K., Santi M., McCarter R., et al. Protein expression of platelet-derived growth factor receptor correlates with malignant histology and PTEN with survival in childhood gliomas. Clin Cancer Res 2008; 14: 3386-3394. 